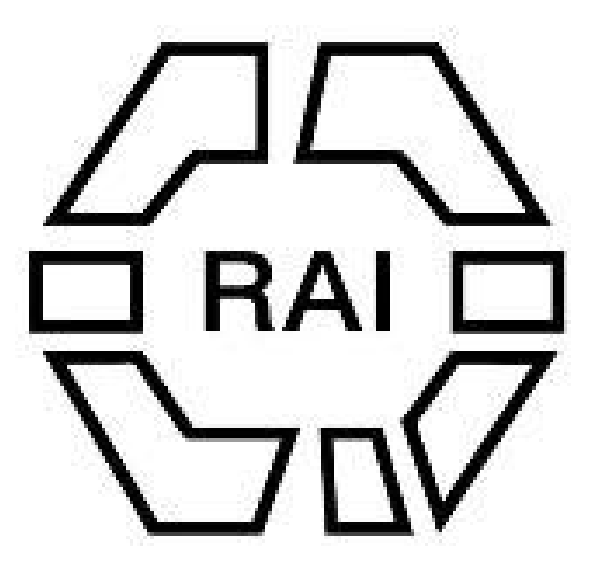

\title{
WILEY
}

The Aborigines of Sungei Ujong

Author(s): F. W. Knocker

Source: The Journal of the Royal Anthropological Institute of Great Britain and Ireland, Vol. 37 (Jul. - Dec., 1907), pp. 290-305

Published by: Royal Anthropological Institute of Great Britain and Ireland

Stable URL: http://www.jstor.org/stable/2843321

Accessed: 22-06-2016 17:21 UTC

Your use of the JSTOR archive indicates your acceptance of the Terms \& Conditions of Use, available at

http://about.jstor.org/terms

JSTOR is a not-for-profit service that helps scholars, researchers, and students discover, use, and build upon a wide range of content in a trusted digital archive. We use information technology and tools to increase productivity and facilitate new forms of scholarship. For more information about JSTOR, please contact support@jstor.org.

Royal Anthropological Institute of Great Britain and Ireland, Wiley are collaborating with JSTOR to digitize, preserve and extend access to The Journal of the Royal Anthropological Institute of Great Britain and Ireland 


\section{THE ABORIGINES OF SUNGEI UJONG. ${ }^{1}$}

By F. W. Knocker, Curator, Perak State Museum.

[With Plates XXV, XXVi.]

As far as I can ascertain, little of an anthropological value has yet been written of the aboriginal races inhabiting the hills of Sungei Ujong. This is perhaps surprising, as the haunts and camping grounds of these tribes are easily accessible; and, indeed, the people are fairly well known to a good many Europeans. The information imparted in this paper, however, concerns more directly those tribes living in the hills which form the north and north-west boundaries of Sungei Ujong. The Balau Hills, which constitute the northern boundary, are the home of the greater number. To the north-west the camps have been considerably broken up by the approach of the railway; and other circumstances accompanying the advance of civilization have helped to scatter the people. A glance at the accompanying sketch map of the old State of Sungei Ujong will give a very fair idea of the geographical range of the wild tribes about to be described. It might, perhaps, be as well to mention here that the State of Sungei Ujong has now been merged into the newer state of Negri Sembilan; but the name is still in use for describing the combined districts of Seremban and the Coast.

The aborigines of Sungei Ujong are popularly known by the name of Orang Bukit, the same name under which certain people in Selangor have been described by Messrs. Annandale and Robinson (vide Fasciculi Malayenses, Anthropology, part 1, pp. 48-57). By many of the Malays living in close contact with them they are also called Orang Raiat, the term commonly used for landowners. Occasionally I have heard them refer to themselves as Sakai; but on being cross-questioned they admitted using the term simply because people persist in calling them by it. They deny positively that they are Sakai or of Sakai origin. They assert that the Sakai is a race of people, small of stature, much smaller than they themselves, living principally at Ulu Pahang and other remote parts of the Peninsula. Further, they say that the Sakai are covered with hair like the beasts of the forest; and that on meeting their own people they are afraid and run away. They have also a legend in respect to the Sakai which tells how the parents plant a parang in the fore-arm of the young, both male and female, projecting a few inches beyond the elbow. The flesh grows round it and it eventually becomes part of the fore-limb. In after life this limb weapon is used to clear the jungle, and not for hostile purposes.

1 Sungei Ujong, formerly an independent British Protected State, is now one of the original nine States which constitute the entire State of Negri Sembilan (Negri=country; Sembilan= nine) and which, together with Perak, Selangor and Pahang, form the British Protectorate of the Federated Malay States. 
There are apparently two distinct races of aborigines in Sungei Ujong-Orang Berlanus ${ }^{1}$ or Mentra, ${ }^{2}$ and Orang Bersisi. ${ }^{3}$ This paper concerns principally the former; but the two races resemble one another closely, and in some parts of the State they interbreed. The principal distinction seems to be the dialect, the Orang Bersisi having one of their own, whilst the Orang Berlanus adopt the Malay language, slightly modified in accent, and with an inflection entirely different to that of the Malays. Out of a list of some three hundred words I was only able to detect the few given in Appendix II as differing entirely from the Malay dialect. These, curiously enough, do not at all resemble the corresponding words in the Bersisi dialect, whilst many of the Bersisi words are identical with words collected from the wild tribes living at the Ulu Plus in Perak. Neither of these races can go back further in their past history than the days when they were hunted and persecuted by the Malays, which lasted until the British Protectorate was established in the State. They suffered severely, in common with the Malays of Sungei Ujong, at the hands of a powerful and warlike race of Malays concen-

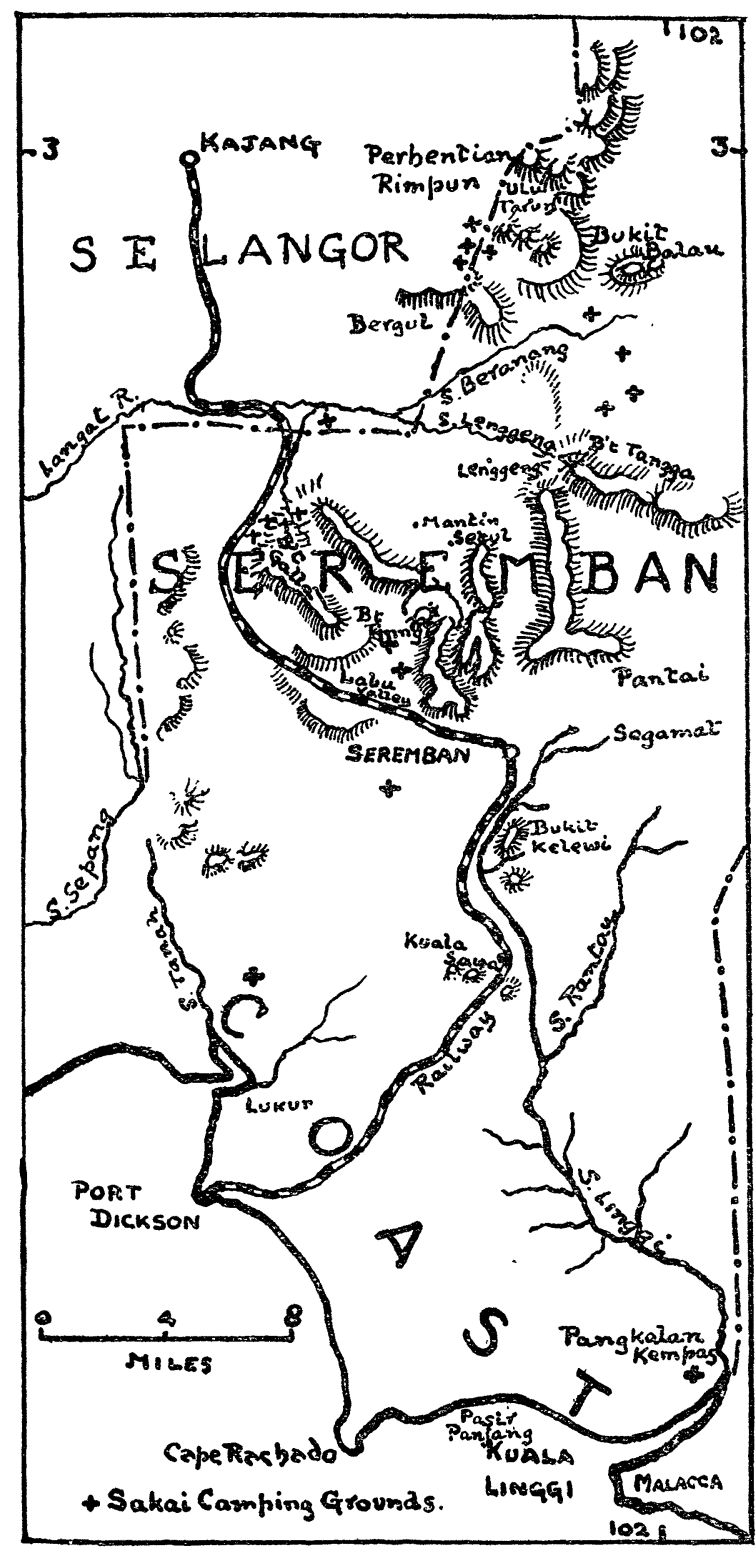

FIG. 1.-SKETCH MAP OF SUNGEI UJONG. trated at Kajang in Selangor, and known as the Orang Rawa. These people constantly raided both the Malays and aborigines of Sungei Ujong, killing the men and seizing the women and children. In those days many members of the tribes living on the Balau Hills fled into Malacca; some of them have since returned and brought back

1 Bèlanxs or Blandas.

* Mantra or Mèntěra.

3 Bĕsisi。 
with them friends made whilst living in that territory, but likewise Orang Berlanus. Living amongst the Balau and Beranang people, also, are men and women from the adjoining district of Jelebu and from the State of Pahang, all claiming to be Orang Berlanus or Mentra. These Pahang people talk of another race in that country called the Orang Sentong, with whom, as also with the Orang Bersisi, they positively assert they do not mix.

In stature the aborigines of Sungei Ujong are short, but well and proportionately built. The average height of the men, taken from thirteen adults, works out at $1.562 \mathrm{~m}$. (say 5 feet $1 \mathrm{inch}$ ), and four adult women give a mean height of $1.436 \mathrm{~m}$. The limbs are stoutly made, and the breasts of the men are developed to a degree of noticeable prominence. The skin, of a reddish brown tint, is quite free from all diseases, and even in aged individuals the form does not reach that degree of emaciation characteristic of aborigines in other parts of the Peninsula. The body and fore-limbs are quite free from hair, but the lower parts of the legs are frequently covered with long wiry hair. In one instance (Batin Jalel) hair was conspicuous on the chest as well as the lower limbs, whilst, on the face, hair of a wiry texture grew abundantly. The hair on the head is black, thick, and, for about an inch from the root, straight, graduating to sharp curls at the end. Sometimes the hair on the head is cut quite short, when its appearance is straight; whilst cut to a few inches in length, it gives a wavy appearance. Occasionally they shave their heads, having a variety of ways of treating it: $(a)$ shaved all over, $(b)$ shaved off on the crown only, leaving a thick halo-shaped mop round the head, (c) shaved off at the back and sides, what is left forming a large tassel over the centre of the forehead, $(d)$ shaved off at the back and on the crown to form a thick semicircular mop in front extending from ear to ear. The women dress their hair similarly to the Malay women, and never cut or shave it, but the curly nature frequently asserts itself.

The face, in the men, is angularly wedge-shaped; but in the women the sharpness of the angles is not so pronounced and can be more precisely described as rounded wedge-shaped. The cheek-bones are high and prominent, but prognathism is entirely absent. The forehead is deep, broad, and very slightly rounded. The nose is narrow and concave at the bridge, widening out below and becoming broad and flat, with nostrils inclined to appear dilated. The eyes are oval: not absolutely almond; in fact, at times (moments of delight and surprise) they are almost round. The pupil is dark brown, and, glanced at casually, might be taken for black. The mouth is large and straight, with thick prominent lips. The teeth, otherwise good, are hopelessly stained, and in old age ruined, by the habitual chewing of sirih, pinang-nut, gambier and tobacco. The children, both boys and girls, are bright and intelligent. Their skin has a lighter shade than the adults, and the body is generally of a healthy appearance. The stomach is always protuberant.

The gait of these aborigines is a short, quick step, palpably originating from the hips, which exhibit movements of great muscular force whilst in motion. Trees 
are climbed by catching hold of the trunk with both hands, throwing out the body and walking up it, as it were. Their powers of endurance are great.

Intellectually the Orang Bukit of Sungei Ujong is wonderfully bright. $\mathrm{He}$ thinks for himself and he acts for hinself, and, moreover, has by far a greater conception and mental grasp of things alien to his nature than more civilized natives of his country. He has a keen sense of wit, and is quick at repartee. The love of animals is another trait deeply rooted in his nature, and every camp has its canine pets as well as domestic fowls. The dogs are slight in build, of a light tawny colour, tail carried in a drooping position and ears pointed and erect. They are very hostile towards white strangers. The men know the wild dog (Śrigalah) well; but on being asked to secure one, either dead or alive, they refused, on the grounds that their affection for them was too great (banyak sayang). To give their remark its due significance, I ought perhaps to state that during the three years I was amongst these people, this was the only request they ever refused me. On the other hand, they lavished on me unasked-for presents of plaited-grass bags and mats made by the women, fowls, eggs, Malacca canes, and fruit from their orchards.

As far as I could ascertain during my long experience and close acquaintanceship with these aborigines, they live a strictly moral life, and adultery and divorce are unknown to them. A man has but one wife at a time, though they see no objection (excepting the very natural one of being unable to provide for more) to a man having two or three wives. They have, apparently, no inclination towards crime or immorality in any form. They possess no idea of warfare or racial strife, and freely admit their preference for a life of seclusion and peace.

The Orang Bukit is born, arrives at man's estate, is married, and eventually dies, without the performance of any ceremony or rite to mark any one of the events. Marriage is merely a mutual compact entered into by the two parties concerned, and co-habitation is sufficient to acknowledge a man and woman as husband and wife. Death is treated in much the same casual way. The corpse is laid to rest on its back in a hole a few feet deep, the relatives mourning the loss for three days; but the "mourning" consists merely of voluntary confinement to the camp. In the event of two or three deaths occurring in the same camp at short intervals, the place is deserted and a fresh camping ground is selected. They have no belief in a spiritual existence in any form after death; and, in one instance, when first questioned on the subject, it seemed to strike them as rather humorous, evoking much laughter. Of ghosts, phantoms, good and evil spirits, supernatural signs or warnings, they apparently know nothing; and I have known many instances when, without the slightest hesitation, they have felled jungle, denounced by Malay and Chinese wood-cutters as haunted.

All the tribes of the Orang Berlanus, in Selangor, Pahang, and other parts of Negri Sembilan as well as Sungei Ujong, have their own chiefs, generally three in number. These, in order of rank, are:-I, Batin, II, Jinang, III, Jok'ra. ${ }^{1}$ The 
Malay title of Pěnglima is also largely in use; but as far as I could ascertain, it carried with it no authority. The Batin is the man respected by the people as their Head; but there is no actual discipline enforced, and they live untrammelled by any self-made laws or rules. The right of succession to a chieftainship passes down to the eldest male child of the late Chief's sister.

The original dress of the aborigines of Sungei Ujong was a loin-cloth made from beaten-out bark. Sarongs, pantaloons, and clothes of various descriptions, obtained by bartering with Malays and Chinese, are now worn by most of them. In the jungle, however, the loin-cloth, now made of a piece of rag, is still the favourite costume. In a few instances the long garb of the Malay-woman (Kabaya) is worn by the women over a sarong. The use of personal ornaments has also been copied from the Malays by many of the females; such as necklaces, brooches, ear-rings and bangles. There is an entire absence of the more primitive methods of body decorations. Nose-quills and skewers are not known to them. Tattooing and painting of the face are not practised, and necklaces of animals' teeth are never made.

The habitations of the Orang Bukit are of a varied character : in some cases extremely primitive, in others more advanced, Malay ideas having become blended with their own. Their original idea of a dwelling, however, appears to be little more than a shelter. The soil is first dug up and then trampled down in order to make a hard floor and to stop the vegetable growth. Around this area is constructed a hut of bark walls, covered by a roof, with sloping sides, made of interlaced palm-leaves. Inside is erected a low platform, not more than a few inches off the ground, composed either of split bamboo or of young trees lashed together with rattan. Over this plaited-grass mats are spread. This type of dwelling is still in vogue amongst the tribes living in the more remote parts of the State and not yet influenced by Malay ideas.

The food of the Orang Berlanus consists principally of rice and the root of the tapioca plant (ubi kayu). These are boiled in a small earthenware pot, procured either from a Malay or Chinaman, and afterwards eaten off a wild banana-leaf " plate." Birds, monkeys, and other animals killed with the blow-pipe are roasted by just throwing the meat on the burnt embers. On rare occasions a fowl is killed, but the eggs are eaten regularly. Water is stored in large bamboos and usually drunk with the aid of a coconut shell or a leaf "cup." They obtain fire by means of ordinary safety matches, but it does not take a very old man to remember the days when flint and steel, procured from the Malays, were used for this purpose. Parangs, forged by Chinese blacksmiths, are now universally used by the aborigines of Sungei Ujong. Obsolete guus, Tower muzzle-loaders and flintlocks can be seen in many of the camps. To use these, they extract the powder from Chinese crackers and load up with miscellaneous oddments of a sufficiently hard nature. Many of these weapons, however, are thrown out of use owing to the difficulty of procuring caps.

The blow-pipe is still the favourite weapon, and both the Orang Berlanus and 
the Orang Bersisi make their own. As in other parts throughout the Peninsula, it consists of an inner and outer tube. The outer tube is always in one piece, but the inner is composed of two lengths joined by a short piece of bamboo. On to the end of this pipe is fixed a trumpet-shaped mouth-piece of a soft wood. This is often coloured a bright scarlet with a "paint" produced from the berries of the rotan jernang, or dragon's blood (Calamus draco). A leaf(dahun) of the palas palm (licuala peltata) is often used to help fix this mouth-piece more firmly to the pipe. The outer tube is bound at both ends with small rings of plaited grass to prevent splitting of the bamboo; and, in addition, the distal extremity is always smeared over thickly with a black resin, for about seven inches. At the aperture this resin is moulded over to form a lip, and as the dart passes through this a sharp whistle is emitted from the pipe. The Orang Bukit says that a blow-pipe which does not give forth this whistle when blown through sharply, is practically useless; for he argues that the whistle speeds the dart and sends it straight to the object aimed at. In substance this should be true, as the narrowing of the aperture by the lip should act as a sort of choke, and without the lip the sound cannot be produced. A portion of this pipe is invariably of a brown shade. The parts left white are decorated with crude geometrical figures, which are scratched with the point of a small knife (golok) and afterwards coloured with charcoal. The average length of a blow-pipe is 7 feet, though they occasionally run to 8 feet and over.

The quiver is made from a large bamboo, and is ornamented with designs similar to those incised on the blow-pipe. The upper part is neatly bound with plaited rattan, leaving about half an inch bare for the cap to fit on. The latter is generally a piece of hollowed-out wood, split here and there to give it the right shape and size to fit the quiver, which is effected exactly by rattan binding. It usually takes the shape of a dome, and is hinged on to the quiver with a piece of string. There is a movable rattan binding (simpai larat) to which is attached the cord for fastening the quiver round the waist. At the bottom of the quiver a patch of resin is always kept for the purpose of fixing on the heads of the darts which invariably become loose. Inside, the darts are kept separately in a skeleton of small canes, the central space of which is reserved for the plugging wool. The darts average $7 \frac{1}{2}$ inches in length, and are made from the hard stem of a grass, fitted with a conical-shaped piece of pith. The other end is sharply pointed and rolled in the poison, being nicked immediately above in order that the tip shall break off in the wound. The poison is produced from the sap of the Upas tree (Antiaris toxicaria) and the leaves of a creeper. It is stored in small cane thimbles, high up inside the huts, presumably out of the reach of the children. In loading the blow-pipe the Orang Bukit first inserts the dart in the mouth of the pipe, and then plugs it with a small portion of the wool. In "firing" he clutches the weapon with both hands close up to the mouth, his upper lip over-laps the mouth-piece and his lower lip is tucked in below. He gives a strong, sharp puff, aiming above the object.

Throughout the country the Orang Berlanus make and play various musical Vos. XXXVII. 
instruments. There are two or three species of flutes. One, the sintoh-wung, ${ }_{1}^{1}$ is about a foot long with five or six small holes, resembling closely the European fife. Another, the tehbong, ${ }^{2}$ is not more than five inches in length, open at one end, a hole bored through the septum at the other, and a large hole in the body of the instrument to blow through. This is clutched in both hands, and, by a skilful manipulation of the tip of the thumb of the left hand over the hole at the septum end, and the lower fleshy part of the thumb of the right hand over the open end, five distinct fluty notes are obtained. A stringed instrument, called the geranting, ${ }^{3}$ is made from a bamboo, 2 inches in diameter and about 15 inches long. This is provided with two, sometimes three, strings (made of finely-pared cane), passed through a hole at the bottom (septum) end, where they are held by a piece of wood, and bound round the instrument at the top end. There is a small wooden bridge, and generally three frets. The instrument has four longitudinal splits of about 10 inches, dividing it into four segments, each with a small hour-glassshaped hole. They also make and play a Jew's harp similar to that of the Malays.

Most of the aboriginal tribes of Sungei Ujong clear a small portion of the jungle in the plains at the foot of their hillside homes, and plant padi. This they have learnt from the Malays, so that their methods of growing and reaping the crop are identical with those of the Malay. Hill padi is also grown in some parts, and Indian corn more frequently. They all cultivate the tapioca plant, the root of which is their favourite food. The people living in the valley of the Labu, and some at Batang Benar, have well-kept settlements with 40-year-old coconut and pinang palms, which would indicate their abandonment of the nomadic existence peculiar to these people throughout the Peninsula. There are also banana palms, sugar-cane, jack-fruit trees and gourds. The people at Kuala Linggi, who are Orang Berlanus, were making an effort three years ago to grow the nipah palm. The aborigines of Sungei Ujong are allowed by Government to make all these clearings and cultivate rent free. They also have orchards, which consist of durian, mangosteen, langsat, rambutan, and other jungle fruit-trees, which they hold free of charge, or in some cases pay a nominal rent of 25 cents per annum. In the event of the land containing these being requisitioned for mining, they receive compensation from the miner.

At the source of the Broga ${ }^{4}$ river in the Balau Hills, the men there carried on for some time a small water-course tin mine, which they worked erratically by primitive methods. The ore washed out was sold or bartered in Broga village; but their nomadic habit prevailing caused the spot to be abandoned. Other sources for bartering are derived from jungle produce, largely in demand by the more civilized native races inhabiting Sungei Ujong; e.g., rattan, bark, wild honey and jungle fruits. They will also barter or sell their labour by felling jungle for the miners and planters.

The Orang Berlanus counts, i.e., what little counting he has to do, as he speaks,

1 Sěntuwang =tuwang-tuwang.

3 Kĕranting.
2 Tèbong=mouthpiece.

${ }_{4}$ Bergul. 
in Malay. He has very little retentiveness for figures, and as far as time is concerned cannot reckon beyond the day after to-morrow. I was fortunate enough once to secure a stick which had been used as a tally for a number of fruit trees for which compensation had to be paid. This has already been described in the Journal of the Federated Malay States Museum, vol. i, No. 2, pp. 60 and 61, Pl. V.

\section{APPENDIX I.}

\section{A Short Vocabulary of the Bersisi [B B̆sisi] Dialect. ${ }^{1}$}

\section{Human Beings.}

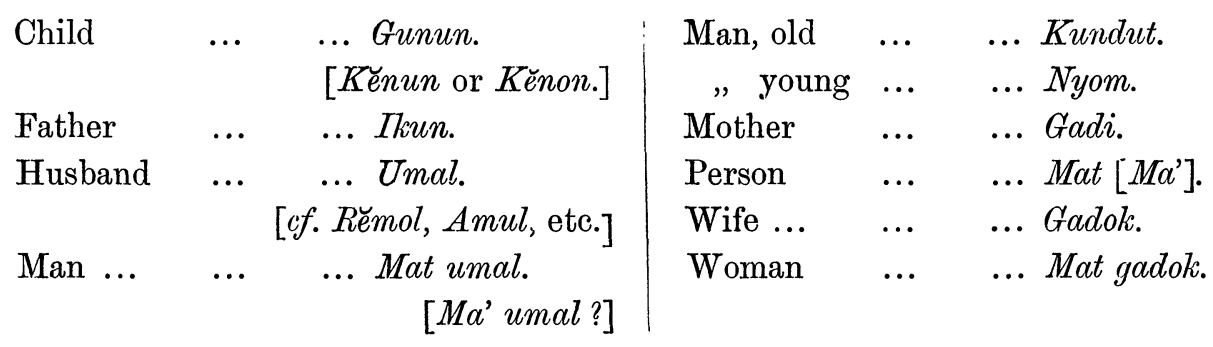

Anatomy.

\begin{tabular}{|c|c|c|c|c|c|}
\hline Arm ... & $\ldots$ & $\begin{array}{l}\text {... Cheleh. } \\
\quad[?=\text { Chĕbeh. }]\end{array}$ & \multirow[t]{2}{*}{$\begin{array}{l}\text { Head } \\
\text { Hips ... }\end{array}$} & \multirow[t]{2}{*}{$\begin{array}{l}\cdots \\
\cdots\end{array}$} & \multirow{2}{*}{$\begin{array}{l}\ldots \text { Kwi.* } \\
\ldots \text { Bantar (M.) } \\
\ldots \text { Lutut. }\end{array}$} \\
\hline Arm-pit & $\ldots$ & ... Kichek. & & & \\
\hline Beard & $\ldots$ & ... Janggut (M.) & & & [M. Lutut.] \\
\hline Blood & $\ldots$ & ... Mahum. & Leg $\ldots$ & $\ldots$ & ... Kejal. \\
\hline Body ... & $\ldots$ & ... Badang (M.) & Moustache & $\ldots$ & ... Mesei. \\
\hline Breasts $q$ & $\ldots$ & ... Doh. & & & [M. Misei.] \\
\hline Chest & $\ldots$ & ... Genal. & Mouth & $\ldots$ & ... Pang. \\
\hline Chin ... & $\ldots$ & ... Chinkuk. & Nail ... & $\ldots$ & $\ldots K u k u(\mathrm{M})$. \\
\hline Ear $\ldots$ & $\ldots$ & ... Tang. & Neck ... & $\ldots$ & ... Leher (M.) \\
\hline Eye $\ldots$ & $\ldots$ & ... Met. & Nose ... & $\ldots$ & $\ldots \operatorname{Mer}^{*}[? M \ddot{\prime}]$ \\
\hline \multicolumn{2}{|c|}{ Finger, index } & - & Skin ... & $\ldots$ & ... Kulit (M.) \\
\hline \multicolumn{2}{|c|}{$\begin{array}{ll} & \text { little... } \\
" & \text { 2nd or 3rd }\end{array}$} & $\operatorname{Jari}$ (M.) & Stomach & $\ldots$ & $\begin{array}{l}\text {.. EE'oich. } \\
\quad \text { [? Öoich or ěoich.] }\end{array}$ \\
\hline Foot $\ldots$ & $\ldots$ & ... Jong. & Teeth... & $\ldots$ & ... Lemang. \\
\hline Fore-arm & $\ldots$ & ... B'ling. & Thigh & $\ldots$ & ... Berluk.* \\
\hline Fore-head & $\ldots$ & $\begin{array}{l}\text {... Kening. } \\
\text { [cf. M. Këning.] }\end{array}$ & Thumb & $\cdots$ & $\begin{array}{l}\quad[? \text { Bĕllu'.] } \\
\ldots I b u \text { jari (M.) }\end{array}$ \\
\hline Hair ... & $\ldots$ & ... Suk. & Wrist & $\ldots$ & ... Singeh. \\
\hline Hand & $\because$ & $\ldots T i^{*}$. & & & \\
\hline
\end{tabular}

1 The standard form of transliteration has been added in square brackets [ ]. 
Clothing, etc.

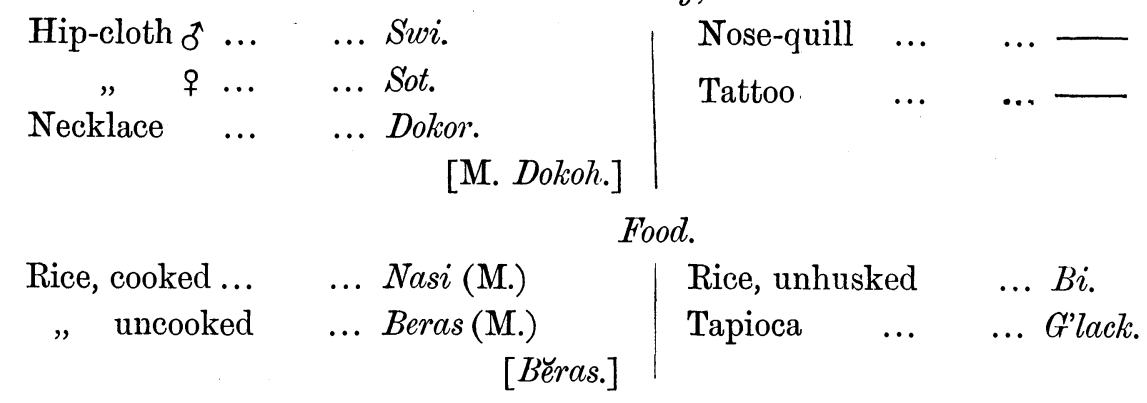

House, etc.

\begin{tabular}{|c|c|c|c|}
\hline $\begin{array}{l}\text { Bed } \ldots . . . \quad \ldots \text { Baring. } \\
\quad[? \text { cf. Mal. Baring, " to recline."] }\end{array}$ & $\begin{array}{l}\text { House } \\
\text { Music }\end{array}$ & $\cdots$ & $\begin{array}{l}\text {.. Dong. } \\
\text {.. Bunyih. }\end{array}$ \\
\hline Box $\ldots \quad \ldots \quad \ldots$ Chok. & & & [M. Bunyi.] \\
\hline ... Pintu (M.) & Plantation & $\cdots$ & ... Umat. \\
\hline Fire ... & & & [M. Huma or Uma.] \\
\hline Floor ... $\quad \ldots \quad \ldots$ Lantok. & Roof ... & $\cdots$ & ... Plong. \\
\hline $\begin{array}{l}\text { [cf. Lantok long }=\text { tree-bark, because } \\
\text { of its material. }]\end{array}$ & $\begin{array}{l}\text { Scent... } \\
\text { Smoke }\end{array}$ & $\ldots$ & $\begin{array}{l}\ldots \text { Bawi (M.) } \\
\ldots \text { Jeluk }\lceil\text { Jěluk]. }\end{array}$ \\
\hline $\begin{aligned} \ldots & \ldots \text { Kumut. } \\
& \quad[? \text { Kĕmut. }]\end{aligned}$ & Window & $\ldots$ & ... Jendela (M.) \\
\hline
\end{tabular}

Weapons, etc.

\begin{tabular}{|c|c|c|c|c|c|}
\hline Blow-pipe & $\ldots$ & ... Balau* [Bĕlau $].$ & Poison & $\ldots$ & ... Ipoh (M.) \\
\hline Darts & $\ldots$ & $\begin{array}{l}\text {.. Damak. } \\
\text { [M. Damak.] }\end{array}$ & Quiver & $\ldots$ & .. Look* $[? L u k]$. \\
\hline
\end{tabular}

Zoology.

(a) Mammals.

\begin{tabular}{|c|c|c|}
\hline Antler & $\ldots$ & ... Gading (M.) \\
\hline Ape, Gibbor & $\ldots$ & $\begin{array}{l}\text {... Timor. } \\
\quad[c f . \text { Tĕmbok. }]\end{array}$ \\
\hline Bear ... & $\ldots$ & ... Bruang (M.) \\
\hline Beast & $\ldots$ & ... Binatang (M.) \\
\hline Boar, wild & $\ldots$ & $\begin{aligned} \ldots & \text { Ketoo. } \\
& {[\text { Ketu or Kĕtu. }] }\end{aligned}$ \\
\hline \multicolumn{2}{|c|}{ Cat, domestic } & ... Kuching (M.) \\
\hline Civet-cat & ... & $\begin{array}{l}\text {... Ginsing. } \\
\text { [? Jinseng. }]\end{array}$ \\
\hline Chevrotain & $\cdots$ & $\begin{array}{l}\text {... Kanchek. } \\
\text { [M. Kanchil.] }\end{array}$ \\
\hline Deer, Barki & & ... Kijang (M.) \\
\hline "Sambu & & ...Rusa (M.) \\
\hline
\end{tabular}

Dog, Domestic _... Jor.

[In neighbouring dialects, Chø̆ or Cho'.]

Dog, Wild ... ... S'rigalah.

$\begin{array}{llll}\text { Elephant } & \ldots & \ldots \text { Merat }[\text { ? Mĕrat }] \text {. } \\ \text { Flying Fox } & \ldots & \ldots \text { Kluang }(\text { M.) } \\ \text { Gaur ... } & \ldots & \ldots \text { S'ladang (M.) } \\ \text { Goat ... } & \ldots & \ldots \text { Kambing (M.) } \\ \text { Horn ... } & \ldots & \ldots \text { Gading }(\text { M.) } \\ \text { Leopard } & \ldots & \ldots \text { Rimau bintang }\end{array}$

(M.)

Monkey, Leaf _... Rotek.

$$
\begin{aligned}
& \text { Macaque } \\
& \text { (M. Cynomolgus) Krah (M.) }
\end{aligned}
$$


Monkey, Macaque

(M. nemestrinus) Kok.

Porcupine ... ... Babi landak (M.)

Rat ... $\quad$... ... Ganek [? Kane'].

Rhinoceros ... ... Badak (M.)

$\begin{array}{lll}\text { Squirrel } & \text {.. } & \text {... Tupai (M.) }\end{array}$

$\begin{array}{llll}\text { Tail ... } & \ldots & \ldots & \text { Ekor (M.) }\end{array}$

Tapir $\quad$... ... Tenok.

[M. Těnok.]

Tiger $\quad \ldots \quad \ldots$ Ahah $\left[A^{\prime} a\right]$.

Tusk $\quad \ldots \quad$... Lamoi.

(b) Birds.

Argus Pheasant ... K'woh.

[M. Kuwau or Kwau.]

Bird $\quad$.. $\quad$... Chim.

Duck $\quad \ldots \quad \ldots$ Iti $[$ M. Itek $]$.

$\operatorname{Egg} \ldots \quad \ldots \quad \ldots$ Kupor [? Kерpo'].

Fowl, Domestic ... Ayam (M.)

Hornbill ... ... Enggang (M.) (c) Reptiles.

Crocodile $\quad$... ... Boya [M. Buaya $]$.

Frog... $\quad \ldots \quad$... Katak (M.)

Lizard $\quad . . \quad$... Chitchak.

[M. Chichak.]

Monitor Lizard ... Biawa (M.)

Snake $\quad$... ... Tigor.

[? Tijå or Tijau.]

(d) Fish.

Fish ... Kah.*

(e) Invertebrates.

Beetle $\quad$... ... Kumbang (M.)

Butterfly ... ... Klebok.

[? Klabok or Kelabok.]

Centipede ... ... Kiyip.

Cicada $\quad$... ... Riang-riang (M.)

Mosquito ... ... Agal.

[? Agai: cf. M. Agas, "sand-fly".]

Sand-fly $\quad \ldots \quad \ldots$ Mai.

Jungle.

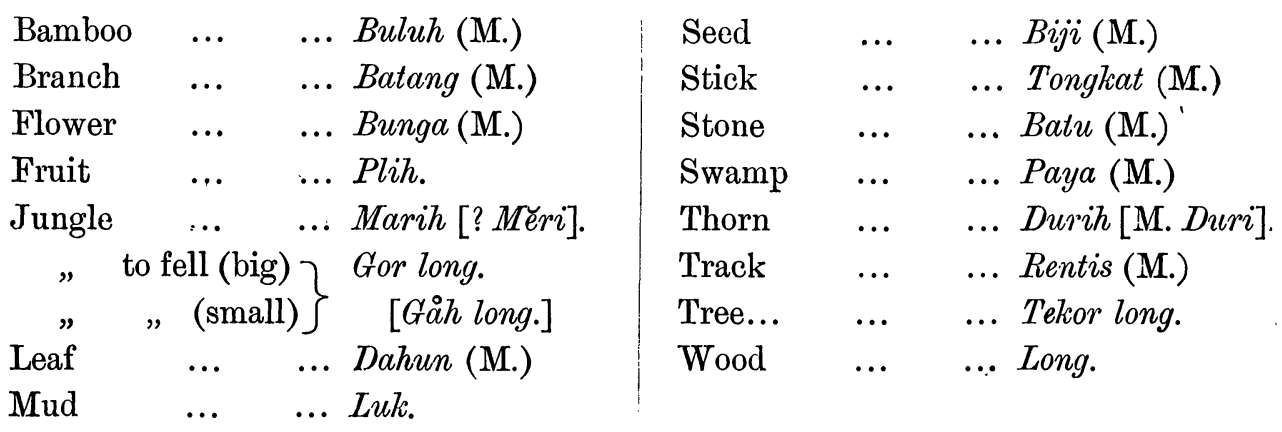

Colours.

$\left.\begin{array}{ll}\text { Black } & \ldots \\ \text { Blue } & \ldots \\ \text { Green } & \ldots\end{array}\right\}$ All Malay words. $\left.\mid \begin{array}{ll}\operatorname{Red} \ldots & \ldots \\ \text { White } & \ldots \\ \text { Yellow } & \ldots\end{array}\right\}$ All Malay words.

Physical Geography, etc.

\begin{tabular}{lll|lll} 
Cape & $\ldots$ & $\ldots$ Tanjong (M.) & Down-stream & $\ldots$ Ilir (M.) \\
Cold & $\ldots$ & $\ldots$ Sejuk $[$ M. Sëjuk]. & Hill & $\ldots$ & $\ldots$ Chong. \\
Day ... & $\ldots$ & $\ldots$ Hari (M.) & Hot ... & $\ldots$ & $\ldots$ Panas (M.) \\
Daylight & $\ldots$ & $\ldots$ Choi. & Land & $\ldots$ & $\ldots$ Teh.*
\end{tabular}


F. W. KNockER.-The Aborigines of Sungei Ujong.

\begin{tabular}{|c|c|c|c|c|c|}
\hline Lightning & $\ldots$ & $\ldots \operatorname{Kilat}(\mathbf{M})$. & \multicolumn{3}{|c|}{ River, source of $\quad \ldots$ Ula (M.) } \\
\hline Moon & $\ldots$ & .. Bulan (M.) & Sea ... & . & .. Laut (M.) \\
\hline Mountain & $\ldots$ & ... Dol. & Sky ... & $\ldots$ & .. Lengat (M.) \\
\hline Night & $\ldots$ & ... Doi. & & & {$[?$ Langet $=\mathrm{M}$. Langit. $]$} \\
\hline Rain & $\cdots$ & ... Gemar. & Star & ... & ... Bintang (M.) \\
\hline & & [? Gëmä or Gĕmar.] & Sun ... & $\ldots$ & ... Mata-hari (M.) \\
\hline Rapid & $\ldots$ & $\begin{array}{l}\text {.. Churan. } \\
\quad \text { [? cf. M. Choram.] }\end{array}$ & $\begin{array}{l}\text { Thunder } \\
\text { Up-stream }\end{array}$ & $\begin{array}{l}\cdots \\
\cdots\end{array}$ & $\begin{array}{l}\ldots \text { Petih [M. Pètir]. } \\
\ldots \text { Ulu (M.) }\end{array}$ \\
\hline $\begin{array}{l}\text { River } \\
\quad, \text { mou }\end{array}$ & ath of & $\begin{array}{l}\text {... Sungei (M.) } \\
\ldots \text { Kuala (M.) }\end{array}$ & Water & ... & ... Doh. \\
\hline
\end{tabular}

Personal Pronoun.

I $\quad \ldots \quad \ldots \quad \ldots H e h[c f . H \bar{e}$ or $H \bar{e}$ ' in neighbouring dialects = you.]

Demonstrative Pronouns.

$\begin{array}{lllll}\text { That } \quad \ldots & \ldots \text { Nenki. } & \text { | This } \quad \ldots & \ldots \text { Nihot }[?=N a h a ̊ .\end{array}$

Adjectives.

\begin{tabular}{|c|c|c|c|c|}
\hline $\operatorname{Bad} \ldots$ & $\ldots$ & $\begin{array}{l}\ldots \text { Suhut. } \\
{\left[? c f . S^{\prime} u t=\text { rotten. }\right]}\end{array}$ & $\begin{array}{l}\text { Little } \\
\text { A little }\end{array}$ & $\begin{array}{l}\text {... Chot. } \\
\text {... Munchut. }\end{array}$ \\
\hline Big ... & ... & ... Kadoi. & Long & ... Jelang. \\
\hline Bitter & $\ldots$ & ... Kedeh. & Old ... & .. Tua (M.) \\
\hline Blind & $\ldots$ & ... Buta (M.) & Round & ... Bulat (M.) \\
\hline Brave & $\ldots$ & ... Brani (M.) & Sharp & ... Bukut. \\
\hline Clean (see & good) & ... Lem. & Short & ... Jelok. \\
\hline Clever & $\begin{array}{l}\ldots \\
{[? \text { Sĕröt }}\end{array}$ & $\begin{array}{l}\text {... Serut. } \\
\text { tor Sérö" = "know."] }\end{array}$ & Slow & $\begin{array}{l}\ldots \\
\ldots \\
\text { pěrlahan (M.) }\end{array}$ \\
\hline Crooked & $\ldots$ & ... Bengkok (M.) & Sour... & ... Assam (M.) \\
\hline Difficult & $\ldots$ & ... Susah (M.) & Strong & .. Kwat (M.) \\
\hline Dirty & $\ldots$ & ... Koto [M. Kotor $]$ & Sweet & ... Manis (M.) \\
\hline Dry ... & $\ldots$ & $\begin{array}{l}\text {... Kering (M.) } \\
{[\text { [Kĕring.] }}\end{array}$ & $\begin{array}{l}\text { Thick } \\
\text { Thin }\end{array}$ & $\begin{array}{l}\ldots \text { Sut. } \\
. . \text { Masen. }\end{array}$ \\
\hline Easy & $\ldots$ & $\begin{array}{r}\text {... Sen'ang (M.) } \\
\text { [Sěnang.] }\end{array}$ & $\begin{array}{l}\text { Thirsty } \\
\text { Tired }\end{array}$ & $\begin{array}{l}\text {.. Chedok. } \\
\text {.. Parät. }\end{array}$ \\
\hline False & $\ldots$ & ... Bohong (M.) & & [M. Pěnat.] \\
\hline Familiar & $\cdots$ & ... Biasa (M.) & True & $\begin{array}{l}\ldots \\
\end{array}$ \\
\hline Fast... & $\ldots$ & ... Ujus. & & [? Nahön or Nahöl = true.] \\
\hline Flat... & $\ldots$ & ... Cheper (M.) & Wet... & ... Tukul. \\
\hline Foolish & $\ldots$ & ... Bodoh (M.) & Wicked & ... Jahat (M.) \\
\hline Good & $\ldots$ & ... Lem. & Wide & ... Lebar [M. Lěbar.] \\
\hline Hungry & $\ldots$ & ... Silih. & Young & $\ldots M u d a(\mathrm{M})$. \\
\hline Lazy & $\ldots$ & ... S'leh. & & \\
\hline
\end{tabular}


Adverbs.

\begin{tabular}{|c|c|c|c|c|c|}
\hline All ... & ... & ... Sumua (M.) & Left ... & $\cdots$ & $\ldots \operatorname{Kiri}(\mathrm{M})$. \\
\hline Before & $\ldots$ & ... Dapan (M.) & Much & $\cdots$ & $\ldots$ Nyum. \\
\hline Behind & $\ldots$ & ... Chelong. & & & [? Nom or \\
\hline & & [? Chĕloñ = back.] & Near & $\ldots$ & ... Meng. \\
\hline Far ... & $\ldots$ & ... Lup. & Right & $\cdots$ & ... Kenan. \\
\hline Here & ... & $\begin{array}{l}\text {... Nihot. } \\
\quad \text { [See "this."] }\end{array}$ & There & $\ldots$ & $\begin{array}{r}{[\text { M. } K} \\
\text {.. Hookih }[H\end{array}$ \\
\hline \multicolumn{6}{|c|}{ Interrogatives. } \\
\hline \multirow{2}{*}{\multicolumn{2}{|c|}{ How many ... }} & ... Berapa (M.) & Where & $\ldots$ & ... Mana (M \\
\hline & & [Bёrapa.] & Why & $\cdots$ & ... Awat (M. \\
\hline What & ... & ... Namat [Nama']. & & & \\
\hline
\end{tabular}

Verbs.

\begin{tabular}{|c|c|c|c|c|c|}
\hline Awaken & $\cdots$ & ... Lek. & Have not & $\ldots$ & ... T'ada (M.) \\
\hline Bite & $\ldots$. & ... Gigit (M.) & Hold & $\ldots$ & ... Pegang (M.) \\
\hline Born & $\ldots$ & ... Kenon. & & & [? Pĕgang.] \\
\hline & & [? Kĕnon, cf. “ child.”] & Kill... & $\ldots$ & ... Kapong. \\
\hline Call ... & $\ldots$ & ... Temor. & Kneel & $\ldots$ & ... No word. \\
\hline Catch & $\cdots$ & $\begin{array}{l}\text { [Témoh or Termong.] } \\
\text {... Igup. }\end{array}$ & Know & $\ldots$ & $\begin{array}{l}\text {.. Surut. } \\
\text { [? Sëröt, see " clever."] }\end{array}$ \\
\hline & & [? Igap or Higap.] & Laugh & $\ldots$ & ... Glok. \\
\hline Climb & $\ldots$ & ... Kayal. & Light & $\ldots$ & ... Lok. \\
\hline Come & $\ldots$ & ...Mai. & Listen & $\ldots$ & ... Kaiyung. \\
\hline & & [cf. M. Mari.] & Live & $\cdots$ & $\ldots$ Yis. \\
\hline Cook & $\ldots$ & ... Tekong. & & & [? Ris = alive. $]$ \\
\hline Cut... & $\ldots$ & ... Kitong. & Look & $\ldots$ & ... Kelau [?Chĕliau]. \\
\hline Dance & $\ldots$ & ... Menari (M.) & Place & $\ldots$ & ... Tahoi. \\
\hline Die ... & $\ldots$ & ... Kubus* [Kěbus]. & \multicolumn{3}{|c|}{ [? cf. tåh $a$ or $t u i=$ that, there. $]$} \\
\hline Do ... & $\ldots$ & ... Kapoi. & Play & $\ldots$ & .. Main-main (M.) \\
\hline Do not & $\ldots$ & $\ldots \operatorname{Bur}[? B \ddot{o}]$. & Prick & ... & ... Tikam (M.) \\
\hline Drink & $\ldots$ & ... Chadoh. & Pull... & .. & ... Kakul. \\
\hline \multicolumn{3}{|c|}{ [? lit. : eat water $=\operatorname{ch} \bar{a}$ doh $($ or $d \ddot{o} \bar{o}) \cdot]$} & Push & ... & ... Tolak (M.) \\
\hline Eat ... & $\ldots$ & ... Chechah.* & Release & $\ldots$ & ... Loh. \\
\hline Extinguisl & a... & ... Lut. & Return & $\ldots$ & ... Yut. \\
\hline Fight & $\ldots$ & $\begin{array}{r}\text {... Gadow (M.) } \\
{[? \text { Gado'.] }}\end{array}$ & $\begin{array}{l}\text { Run... } \\
\text { See ... }\end{array}$ & $\begin{array}{l}\cdots \\
\cdots\end{array}$ & $\begin{array}{l}\ldots \text { Dut [? Duh]. } \\
\ldots \text { Kaiyi. }\end{array}$ \\
\hline Give & ... & ... Kajun. & Shake & $\ldots$ & ... Goyang (M.) \\
\hline Go $\ldots$ & $\therefore$ & ... Chochor. & Sick (to be & )... & ... Gehup. \\
\hline Have & $\ldots$ & $\ldots \operatorname{Ada}(\mathrm{M})$. & $"$ (feve & & ... Tekat [těkat]. \\
\hline
\end{tabular}




\begin{tabular}{|c|c|c|c|c|}
\hline Sing... & ... Menanyi (M.) & Take & $\cdots$ & ... Kakul. \\
\hline Sit $\ldots$ & $\ldots K u m$. & & & [Bërěnang.] \\
\hline Sleep & ... Jitik. & Tell... & $\ldots$ & ... Bilang (M.) \\
\hline Smell & ... Hun. & Wait & $\ldots$ & ... Doi. \\
\hline Speak & .. Chakap (M.) & Walk & $\ldots$ & ... Yor. \\
\hline Stand & ... Jun [? Jöng]. & Want & $\ldots$ & ... Gah. \\
\hline Stare & ... Pengong. & Wash & $\ldots$ & ... Chuchi (M.) \\
\hline Steal & ... Sisit. & Weep & $\ldots$ & ... Nyum. \\
\hline [See & $\begin{array}{l}\text { “Thief," in Plus Sakai } \\
\text { vocabulary.] }\end{array}$ & Work & $\ldots$ & $\begin{aligned} & {[? \text { Nyam or yam.] }} \\
& \ldots \text { Kerja (M.) }\end{aligned}$ \\
\hline Strike & .. $\quad \ldots$ Kapet. & & & [? Kĕrrja.] \\
\hline Swim & ... Beranang (M.) & Wound & .. & ... P'ris. \\
\hline
\end{tabular}

Numerals.
One... $\quad \ldots \quad \ldots M o i$.
Three
... Umpih [ёmpi'].
Two... $\quad \ldots \quad \ldots M a$.
From " 4 " onwards the numbers are borrowed from the Malay language.

Obs.-There is no word for ghost, good or evil spirit, etc.

N.B.-Words marked "(M.)" are Malay words actually in use among the Orang Bersisi.

Words marked * coincide with the Ulu Plus words.

The pronunciation of the words is based on that used in Swettenham's Malay Dictionary [but there are exceptions, e.g., Ketoo $=$ Kětu (pig) and hookih = huki (there), etc.]-ED.

\section{APPENDIX II.}

A Short List of Words in use among the Orang Berlanus [BĔLanas.]

\begin{tabular}{|c|c|c|c|c|c|}
\hline Father & $\ldots$ & $\begin{array}{l}\text {... Bapai. } \\
\quad[\text { Mal. Bapa. }]\end{array}$ & Forearm & $\ldots$ & $\begin{array}{l}\text {.. Jebeh. } \\
\text { [? Jěbeh or Chĕbeh.] }\end{array}$ \\
\hline Mother & $\ldots$ & ...Moi. & Forehead & $\cdots$ & ... Kening. \\
\hline Child & $\ldots$ & $\begin{array}{l}\text {.. Enek. } \\
\text { [cf. Malay "Anak."] }\end{array}$ & & & [cf. Mal. Kěning.] \\
\hline Wife & $\ldots$ & ... Awak. & Elephant & $\ldots$ & ... Permasil. \\
\hline Husband & $\ldots$ & ...Awak. & Tiger & $\ldots$ & ... Gubin. \\
\hline Malay & $\ldots$ & ... Jebok [Jěbo']. & [in $\mathrm{n}$ & iohb & ing dialect $=$ "dog."” \\
\hline
\end{tabular}


F. W. KNocker.-The Aborigines of Sungei Ujong.

\begin{tabular}{|c|c|c|c|c|c|}
\hline $\begin{array}{l}\text { Wild pig } \\
\text { Porcupine }\end{array}$ & $\ldots$ & $\begin{array}{l}\ldots \text { Isim [cf. Risim. }] \\
\ldots \text { Latoi. }\end{array}$ & Give & & $\begin{array}{l}\text {.. Berip. } \\
\quad[c f . \text { Mal. Bĕri. }]\end{array}$ \\
\hline Deer (Sam & bur) & ... Guntau. & Cut ... & $\cdots$ & ... Kerat. \\
\hline Butterfly & ... & ... Clabok. & & & [Mal. Kĕrc \\
\hline Mosquito & $\ldots$ & $\begin{array}{l}\text { [Klabok or Kĕlabok.] } \\
\text {... Gemos }\end{array}$ & Raise & $\ldots$ & $\begin{array}{l}\ldots \text { Bawai. }^{1} \\
\quad[\text { Mal. Bawa. }]\end{array}$ \\
\hline & & [or Këmus.] & Quarrel & $\ldots$ & $\begin{aligned} \text {.. Klahih. } \\
\\
\text { [Mal. Bĕrkĕlahi.] }\end{aligned}$ \\
\hline Jungle & $\cdots$ & $\begin{array}{l}\ldots \text { Rimah. } \\
\quad \text { [Mal. Rimba.] }\end{array}$ & $\begin{array}{l}\text { Wash } \\
\quad[c f . \text { Mal. }\end{array}$ & Sapu, & $\begin{array}{l}\text {... Sapoi. } \\
\text { to wipe," "to sweep. }\end{array}$ \\
\hline Tree & $\ldots$ & $\begin{array}{l}\text {... Pohun. } \\
\quad \text { [Mal. Pohon. }]\end{array}$ & $\begin{array}{l}\text { All } \ldots . \\
\text { No } \ldots \\
\text { Lazy }\end{array}$ & $\begin{array}{l}\cdots \\
\cdots \\
\ldots\end{array}$ & $\begin{array}{l}\text {.. Mahit. } \\
\text {.. Nyap. } \\
\text {.. Plasup. }\end{array}$ \\
\hline Come & $\ldots$ & $\begin{array}{l}\ldots \text { Mai. } \\
\quad \text { [cf. Mal. Mari. }]\end{array}$ & Dry... & $\begin{array}{l}\cdots \\
{[? c f}\end{array}$ & $\begin{array}{l}\text {... Tohu. } \\
\text { Mal. tohor, " shallow. }\end{array}$ \\
\hline
\end{tabular}

Terms used by the "Orang Berlanus" (Bèlanas) for the different parts of the blow-pipe and quiver.

$\begin{array}{lccccl}\text { Blow-pipe } & \ldots & \ldots & \ldots & \ldots & \text { Temiang [Témiang]. } \\ \text { Outer pipe } & \ldots & \ldots & \ldots & \ldots & \text { Tagor. } \\ \text { Inner } & \ldots & \ldots & \ldots & \ldots & \text { Anak temiang. } \\ \text { Mouth of blow-pipe } & \ldots & \ldots & \ldots & \text { Tebong [Tëbong]. } \\ \text { Distal end of blow-pipe } & \ldots & \ldots & \text { Lengai. }\end{array}$

Inside of ditto, which is made with resin in the shape of a "lip" to increase the speed of the dart ... Sengloh.

Resin on the distal end of blow-pipe... Gelah.

Ornamentation on blow-pipe ... $\quad \ldots \quad$ Hokeh [cf. Mal. Ukir ].

$\begin{array}{llllll}\text { Quiver ... } & \ldots & \ldots & \ldots & \ldots & \text { T"lah. }\end{array}$

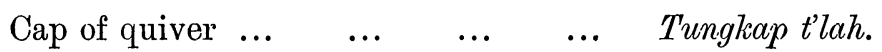

Bindings around quiver, in order from (1) Simpai tujoh: (2) Simpailapan; the top.

Patch of resin on bottom of quiver to fix head on darts... . ... ... Kaboh t'lah.

Darts $\quad \ldots \quad \ldots \quad \ldots \quad \ldots \quad \ldots \quad \ldots \quad$ Damak [Mal. Damak].

Head of dart $\begin{array}{llllll}\text {... } & \ldots & \ldots & \ldots & \text { Pabong. }\end{array}$

Cases for dart $\ldots \quad \ldots \quad \ldots \quad \ldots \quad P^{\prime} l e k \quad\left[\begin{array}{lll}\text { in neighbouring dialects, } \\ \text { n }\end{array}\right.$

Down for plugging mouth of blow-pipe when "firing $\quad \ldots \quad \ldots \quad \ldots \quad$ Rabok $[$ Mal. Rabok $]$. bawa].

1 The usual Malay word for "raise" is angkat, which also means "to carry or bring" [Mal. 


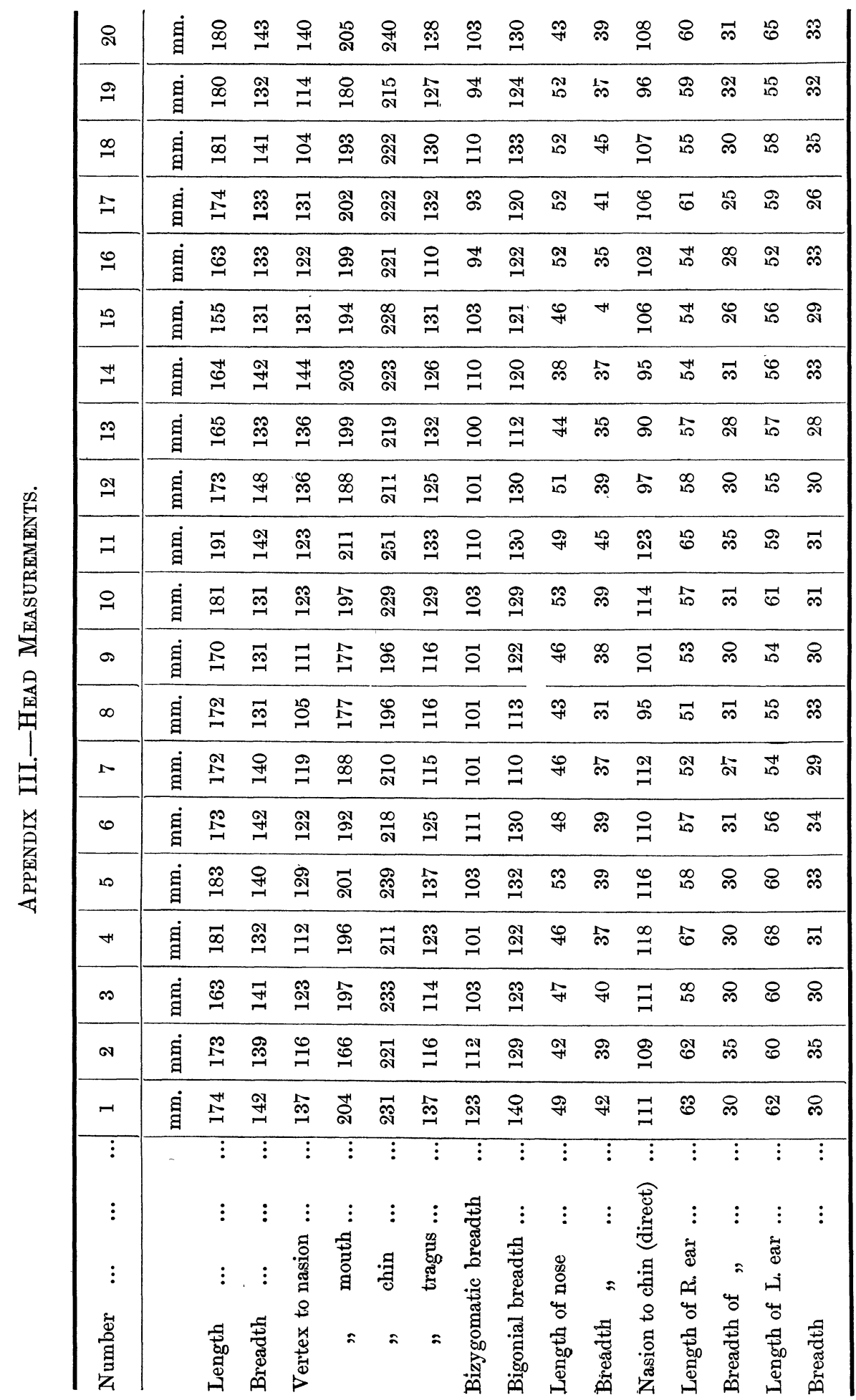




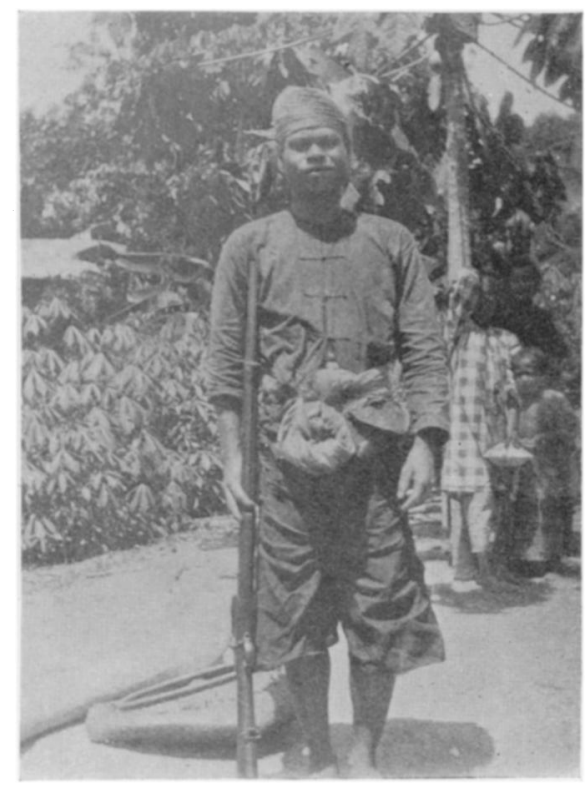

FIG. 1.-ORANG BUKIT (BĔLANAS). (SEE APP. IV, NO. 2.)

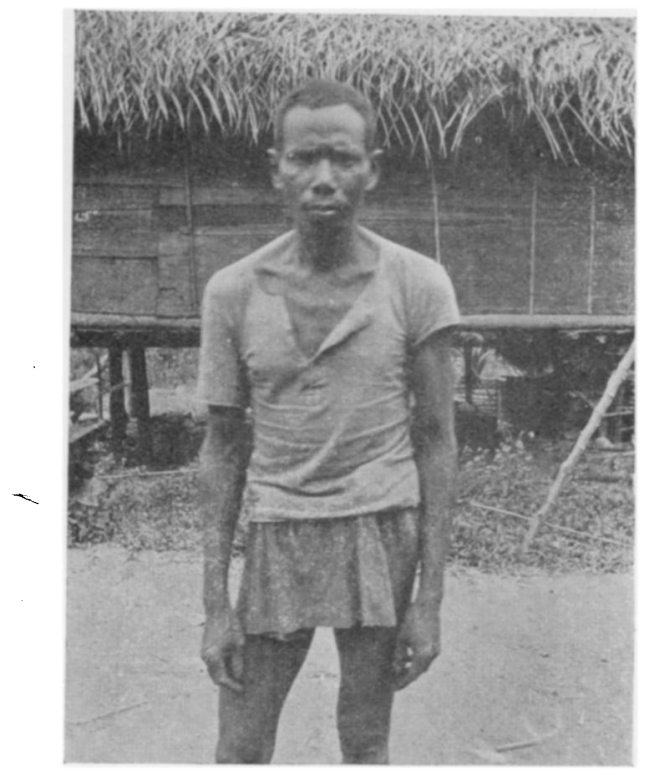

FIG. 2.-ORANG BUKIT (BĔLANAS). (SEE APP. IV, NO. 4.)
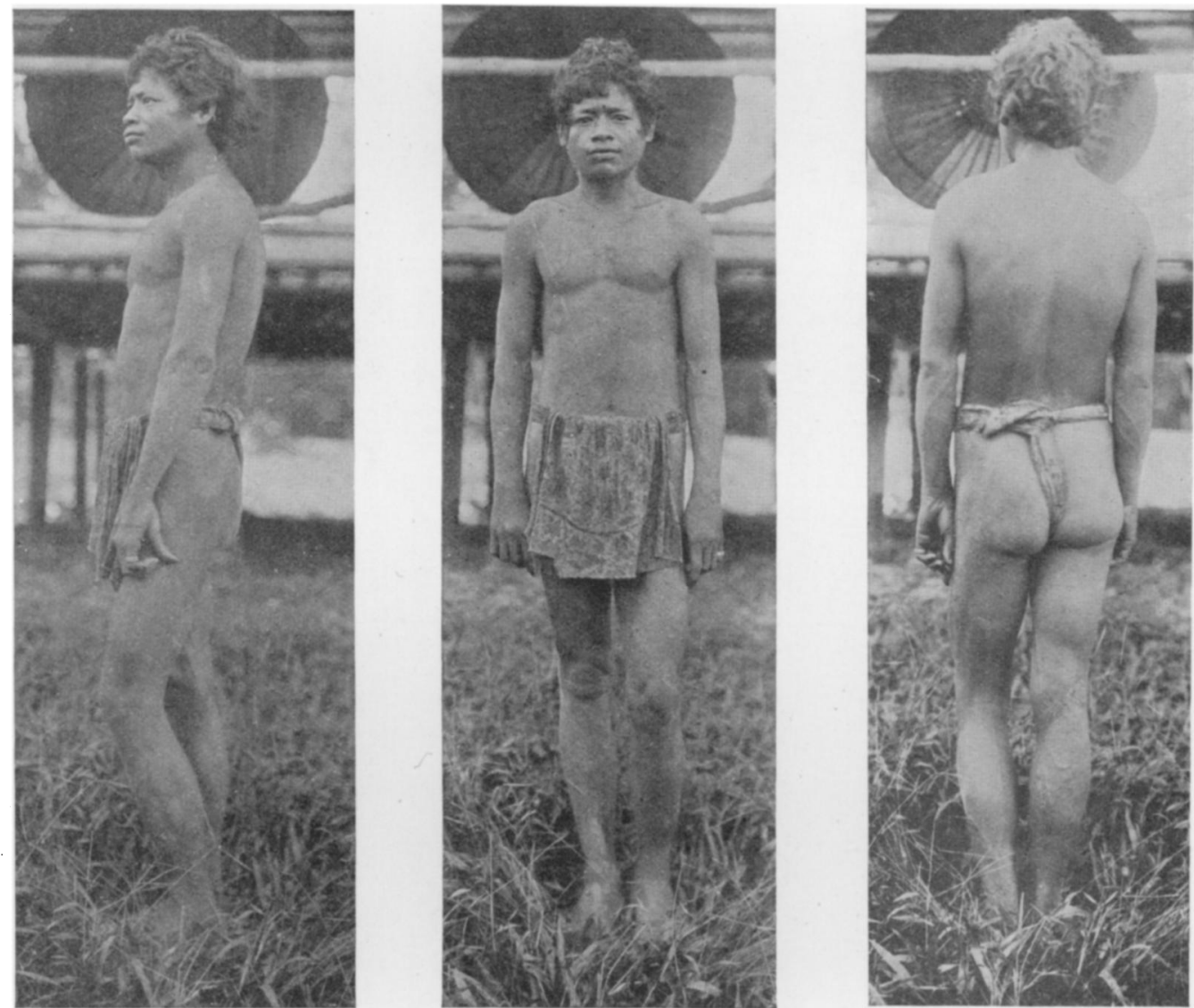

FIGS. 3, 4, 5. - ORANG BUKIT : HALF CASTE BĔSISI AND BĔLANAS.

(SEE APP. IV, NO. 17.)

THE ABORIGINES OF SUNGEI UJONG. 


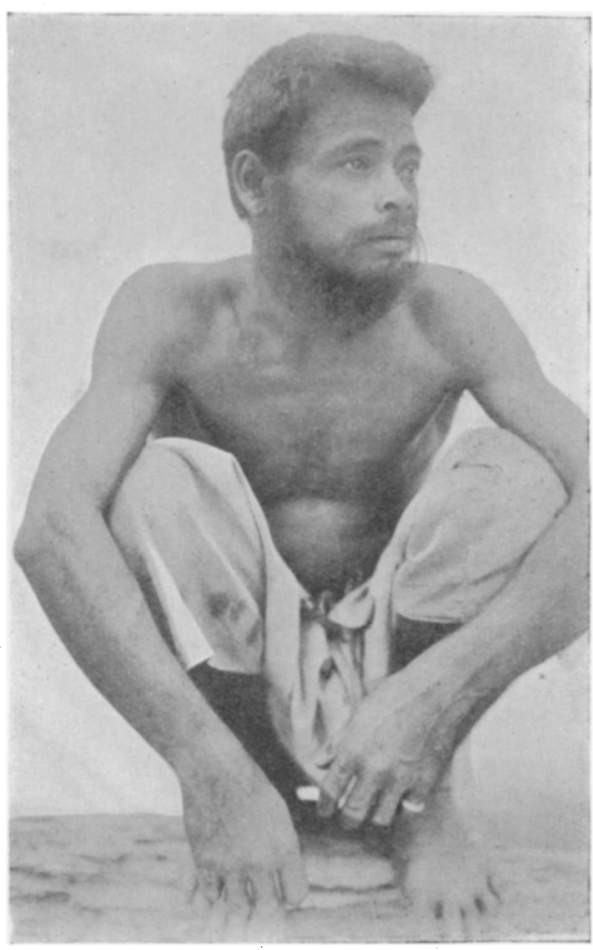

Hig. 1. - ORANG bUKIt (BĔlaNas). (SEE APP. IV, No. 1.)

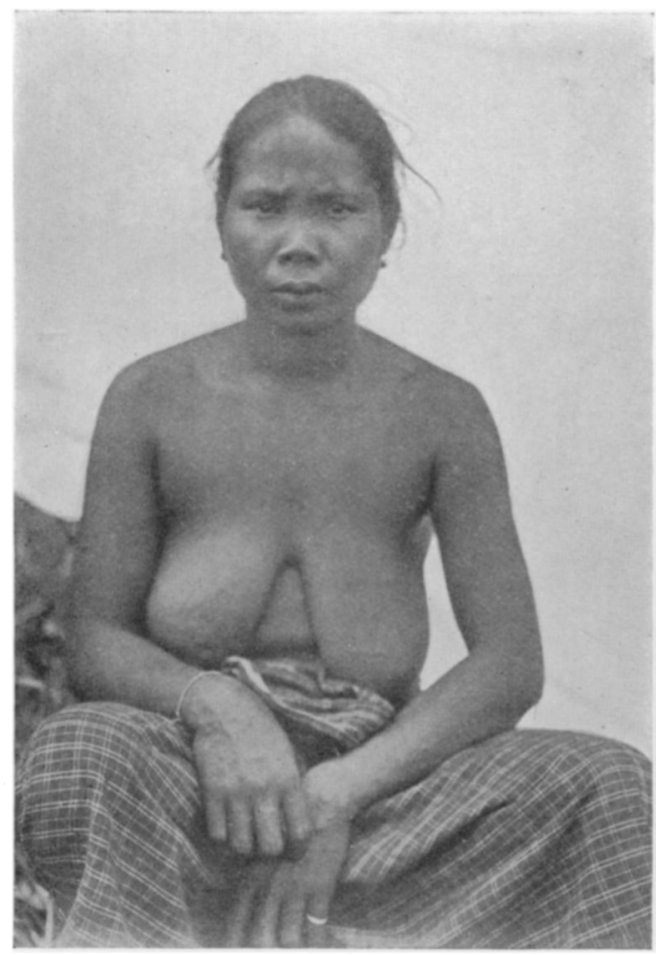

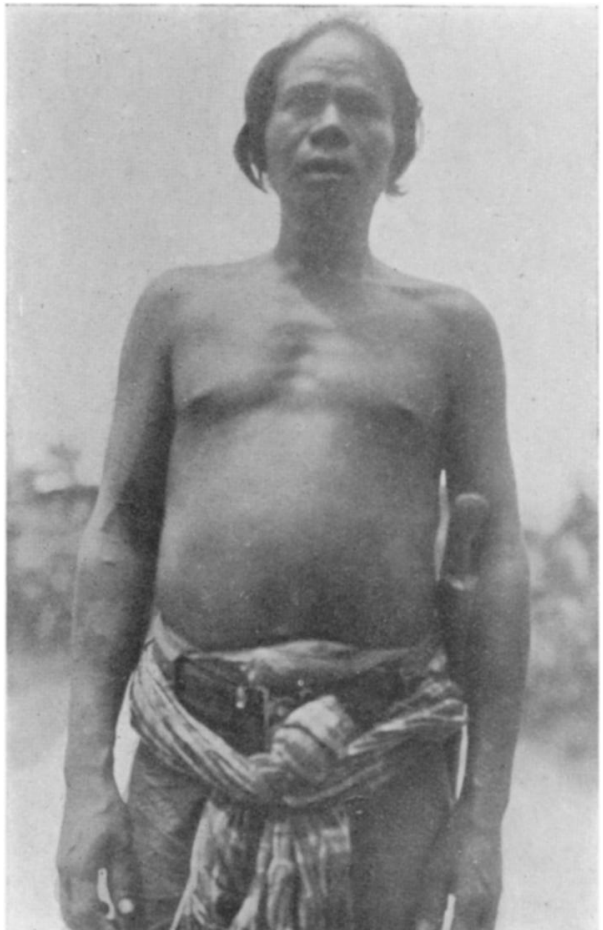

FIG. 2.-ORANG BUKIT (BĔLANAS). (SEE APP. 1V, No. 11.)

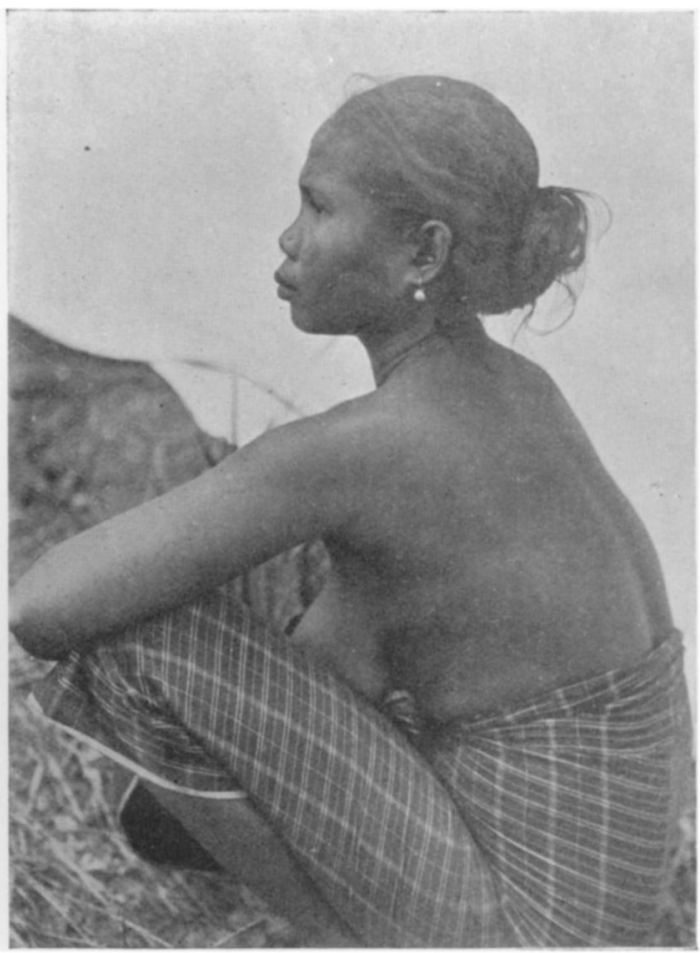

FIGS. 3 AND 4.-ORANG BUKIT (BĔLANAS). (SEE APP. IV, No. 12.) THE ABORIGINES OF SUNGEI UJONG. 


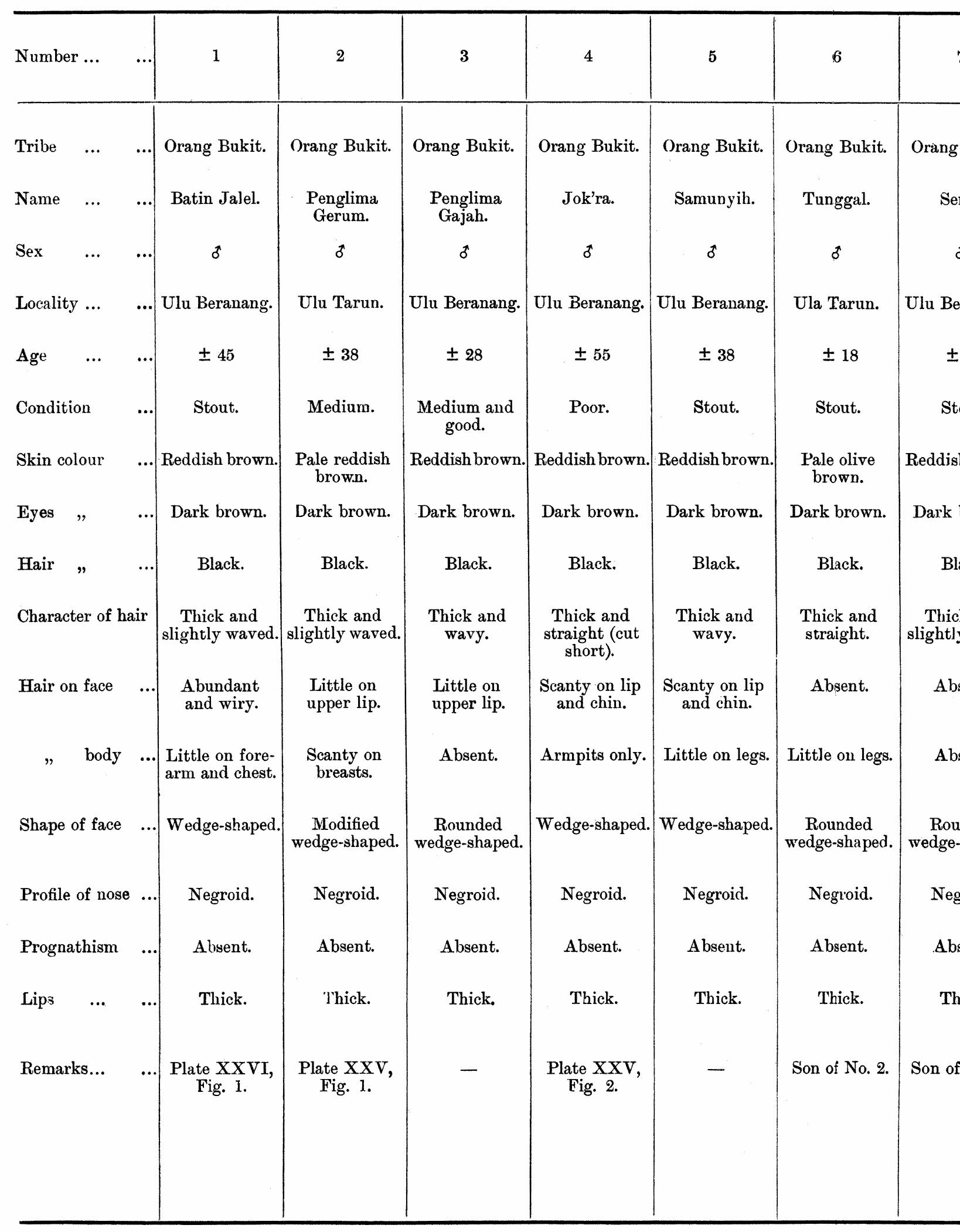




\begin{tabular}{|c|c|c|c|c|c|c|c|c|}
\hline 6 & 7 & 8 & 9 & 10 & 11 & 12 & 13 & \\
\hline ang Bukit. & Orang Bukit. & Orang Bukit. & Orang Bukit. & Orang Bukit. & Orang Bukit. & Orang Bukit. & Orang Bukit. & Orang \\
\hline Tunggal. & Senot. & Kulup. & G'lek. & Sengor Raja. & $\begin{array}{l}\text { Penglima } \\
\text { Hitam. }\end{array}$ & Ladek. & Jekas. & S'I \\
\hline$\delta$ & t & c & $\delta$ & $\delta$ & $\delta$ & 우 & q & \\
\hline la Tarun. & Ulu Beranang. & Ulu Beranang. & Ulu Beranang. & Ulu Beranang. & Ulu Tarun. & Ulu Beranang. & Ulu Beranang. & Ulu Ber \\
\hline \pm 18 & \pm 12 & \pm 9 & \pm 14 & \pm 30 & \pm 40 & \pm 38 & \pm 30 & \pm \\
\hline Stout. & Stout. & Medium. & Stout. & Medium. & Stout. & Mediun. & Medium. & St \\
\hline $\begin{array}{l}\text { ale olive } \\
\text { brown. }\end{array}$ & Reddishbrown. & Reddishbrown. & Reddish brown. & Olive brown. & Reddish brown. & $\begin{array}{c}\text { Dark olive } \\
\text { brown. }\end{array}$ & $\begin{array}{l}\text { Dark olive } \\
\text { brown. }\end{array}$ & Reddish \\
\hline ark brown. & Dark brown. & Dark brown. & Dark brown. & Dark brown. & Dark brown. & Dark brown. & Dark brown. & Dark \\
\hline Black. & Black. & Black. & Black. & Black. & Black. & Black. & Black. & $\mathrm{Bla}$ \\
\hline $\begin{array}{l}\text { Whick and } \\
\text { straight. }\end{array}$ & $\begin{array}{c}\text { Thick and } \\
\text { slightly wavy. }\end{array}$ & $\begin{array}{l}\text { Thick and } \\
\text { straight. }\end{array}$ & $\begin{array}{l}\text { Thick and } \\
\text { straight } \\
\text { (cut short). }\end{array}$ & Wavy. & $\begin{array}{l}\text { Thick and } \\
\text { wavy. }\end{array}$ & $\begin{array}{l}\text { Abundant- } \\
\text { long and } \\
\text { straight. }\end{array}$ & $\begin{array}{l}\text { Abundant- } \\
\text { long and } \\
\text { straight. }\end{array}$ & $\begin{array}{c}\text { Abund } \\
\text { long } \\
\text { strai }\end{array}$ \\
\hline Absent. & Absent. & Absent. & Absent. & $\begin{array}{l}\text { Scanty on lip } \\
\text { and chin. }\end{array}$ & Scanty. & Absent. & Absent. & $\mathrm{Abs}$ \\
\hline tle on legs. & Absent. & Absent. & Absent. & $\begin{array}{l}\text { Absent_little } \\
\text { on legs. }\end{array}$ & $\begin{array}{c}\text { Absent-little } \\
\text { on legs. }\end{array}$ & Absent. & Absent. & $\mathrm{Abs}$ \\
\hline $\begin{array}{l}\text { Rounded } \\
\text { dge-shaped. }\end{array}$ & $\begin{array}{c}\text { Rounded } \\
\text { wedge-shaped. }\end{array}$ & Wedge-shaped. & Wedge-shaped. & Wedge-shaped. & Wedge-shaped. & $\begin{array}{c}\text { Plump } \\
\text { wedge-shaped. }\end{array}$ & $\begin{array}{c}\text { Full } \\
\text { wedge-shaped. }\end{array}$ & $\begin{array}{r}\mathrm{Fu} \\
\text { wedge-s }\end{array}$ \\
\hline Negroid. & Negroid. & Negroid. & Negroid. & Negroid. & Negroid. & Negroid. & Negroid. & Negr \\
\hline Absent. & Absent. & Absent. & Absent. & Absent. & Absent. & Absent. & Absent. & $\mathbf{A l}$ \\
\hline Thick. & Thick. & Thick. & Thick. & Thick. & Thick. & Thick. & Thick. & $\mathrm{Tl}$ \\
\hline n of No. 2. & Son of No. 1. & Son of No. 4. & - & - & $\begin{array}{l}\text { This man came } \\
\text { from Pahang } \\
\text { years ago. } \\
\text { Plate XXVI, } \\
\text { Fig. } 2 .\end{array}$ & $\begin{array}{l}1 \text { child } \stackrel{9}{ } \\
\text { Plate XXVI, } \\
\text { Figs. } 3 \text { and } 4 .\end{array}$ & Wife of No. 10. & $\begin{array}{c}\text { One } \\
\text { dea }\end{array}$ \\
\hline
\end{tabular}




\begin{tabular}{|c|c|c|c|c|c|c|c|}
\hline 13 & 14 & 15 & 16 & 17 & 18 & 19 & 20 \\
\hline ng Bukit. & Orang Bukit. & Orang Bukit. & Orang Bukit. & Orang Bukit. & Orang Bukit. & Orang Bukit. & Orang Bukit. \\
\hline Jekas. & S'Inah. & Mangih. & Burok. & Kulup. & Petrus D'ris. & $\begin{array}{l}\text { Penglima } \\
\text { Tahat. }\end{array}$ & Kulup Tepai. \\
\hline$q$ & $q$ & $q$ & $\delta$ & 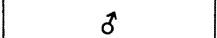 & to & to & 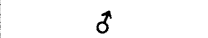 \\
\hline Beranang. & Ulu Beranang. & Ulu Beranang. & Ulu Beranang. & Batang Labu. & Batang Labu. & Batang Labu. & Batang Labu. \\
\hline \pm 30 & \pm 26 & \pm 40 & \pm 28 & \pm 20 & \pm 38 & \pm 50 & \pm 28 \\
\hline Cedium. & Stout. & Medium. & Medium. & Medium. & Stout. & Poor. & Medium. \\
\hline rk olive & Reddish brown. & Olive brown. & Reddish brown. & Reddish brown. & Reddish brown. & Olive brown. & Reddish brown \\
\hline k brown. & Dark brown. & Dark brown. & Dark brown. & Dark brown. & Dark brown. & Dark brown. & Dark brown. \\
\hline Black. & Black. & Black. & Black. & Black. & Black. & Black-grey & Black. \\
\hline $\begin{array}{l}\text { undant- } \\
\text { ng and } \\
\text { raight. }\end{array}$ & $\begin{array}{l}\text { Abundant- } \\
\text { long and } \\
\text { straight. }\end{array}$ & $\begin{array}{l}\text { Long and } \\
\text { straight. }\end{array}$ & $\begin{array}{l}\text { Cut short, } \\
\text { straight. }\end{array}$ & $\begin{array}{c}\text { Thick and } \\
\text { wavy. }\end{array}$ & $\begin{array}{c}\text { Thick and } \\
\text { slightly wavy. }\end{array}$ & $\begin{array}{l}\text { Straight. } \\
\text { (cut short). }\end{array}$ & $\begin{array}{l}\text { Straight } \\
\text { (cut short }\end{array}$ \\
\hline dbsent. & Absent. & Absent. & Clean shaven. & Absent. & $\begin{array}{l}\text { Scanty on lip } \\
\text { and chin. }\end{array}$ & $\begin{array}{l}\text { Scanty on lip } \\
\text { and chin. }\end{array}$ & $\begin{array}{l}\text { Plentiful } \\
\text { (shaves). }\end{array}$ \\
\hline Ibsent. & Absent. & Absent. & Absent. & Absent. & $\underset{\text { scanty on leg. }}{\text { Absent- }}$ & Absent. & Plentiful. \\
\hline $\begin{array}{l}\text { Full } \\
\text { ge-shaped. }\end{array}$ & $\begin{array}{c}\text { Full } \\
\text { wedge-shaped. }\end{array}$ & $\begin{array}{c}\text { Full } \\
\text { wedge-shaped. }\end{array}$ & $\begin{array}{c}\text { Modified } \\
\text { wedge-shaped. }\end{array}$ & $\begin{array}{c}\text { Modified } \\
\text { wedge-shaped. }\end{array}$ & $\begin{array}{c}\text { Rounded } \\
\text { wedge-shaped. }\end{array}$ & Wedge-shaped. & Wedge-shaped. \\
\hline Tegroid. & Negroid. & Negroid. & $\begin{array}{l}\text { Negroid (not } \\
\text { pronounced). }\end{array}$ & Negroid. & Negroid. & Negroid. & Negroid. \\
\hline Absent. & Absent. & Absent. & Absent. & Absent. & Absent. & Absent. & Absent. \\
\hline Thick. & Thick. & Thick. & $\begin{array}{l}\text { Thick, not so } \\
\text { thick as others. }\end{array}$ & Thick. & $\begin{array}{c}\text { Medium, not } \\
\text { so thick as } \\
\text { No. } 17 \text {. }\end{array}$ & Thick. & Thick. \\
\hline of No. 10. & $\begin{array}{l}\text { One child } \\
\text { dead. }\end{array}$ & $\begin{array}{l}\text { Wife of No. } 1, \\
6 \text { children, } \\
5 \text { ठ, } 1 \text { \%. }\end{array}$ & - & \begin{tabular}{|} 
This man was \\
an Orang \\
Bersisi half \\
caste Orang \\
Berlanus. \\
Plate XXV, \\
Figs. 3,4 and 5.
\end{tabular} & - & - & - \\
\hline
\end{tabular}




\begin{tabular}{|c|c|}
\hline & $\Rightarrow \quad \Rightarrow \quad=$ \\
\hline$\stackrel{\sim}{\sim}$ & 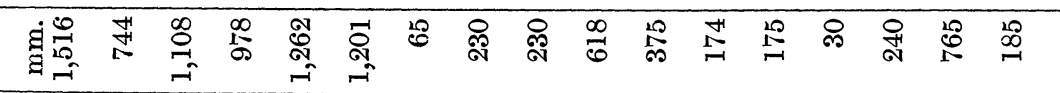 \\
\hline$\stackrel{\infty}{\sim}$ & 弯季 \\
\hline$\approx$ & 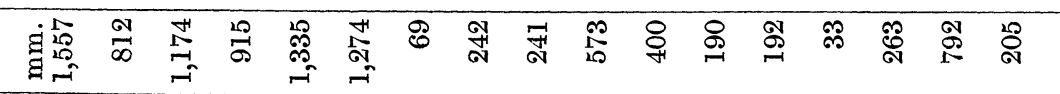 \\
\hline 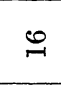 & 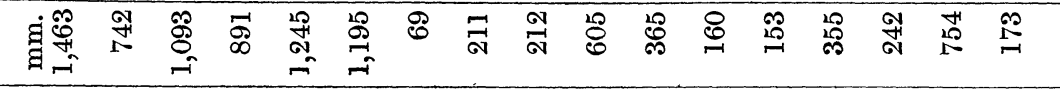 \\
\hline$\stackrel{29}{-1}$ & 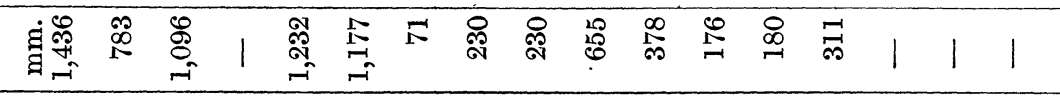 \\
\hline$\stackrel{H}{\sim}$ & 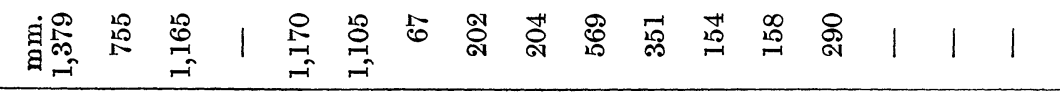 \\
\hline$\cong$ & 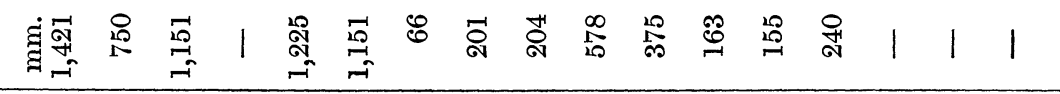 \\
\hline 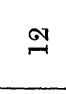 & 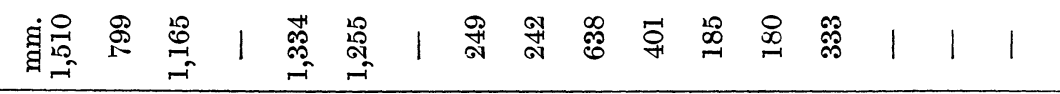 \\
\hline$\Rightarrow$ & 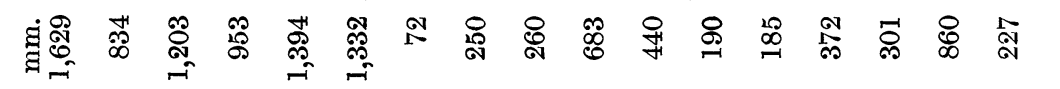 \\
\hline 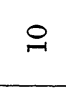 & 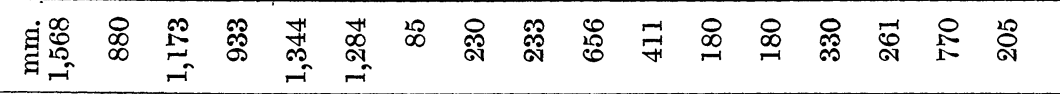 \\
\hline$\theta$ & 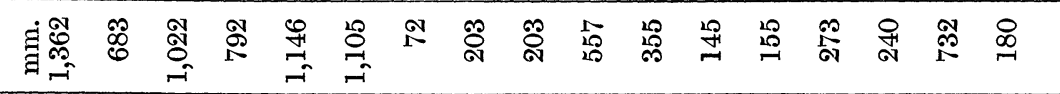 \\
\hline$\infty$ & 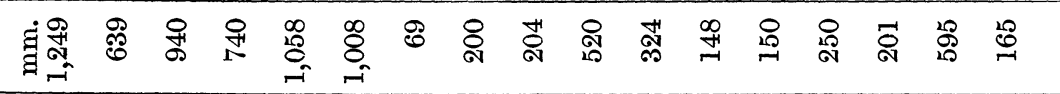 \\
\hline s & 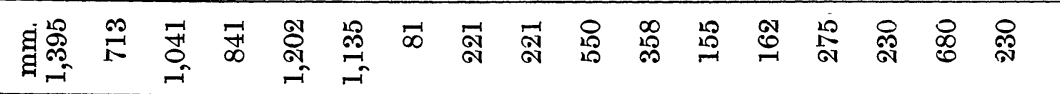 \\
\hline$\circ$ & 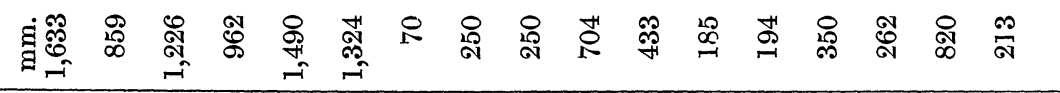 \\
\hline$\therefore$ & 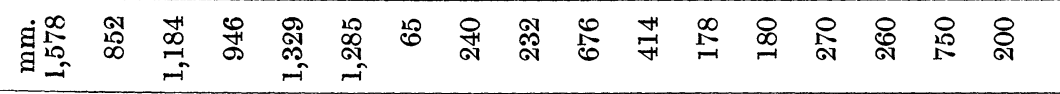 \\
\hline$\nleftarrow$ & 承迠 \\
\hline$\infty$ & 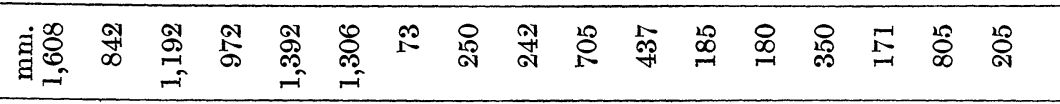 \\
\hline ๙ & 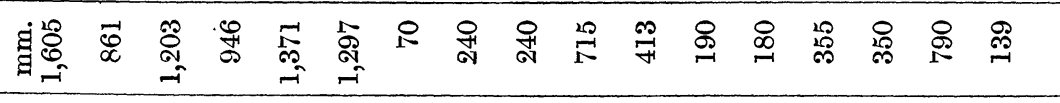 \\
\hline- & 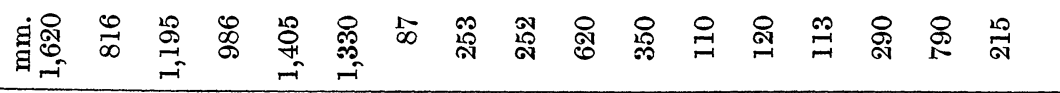 \\
\hline$\vdots$ & 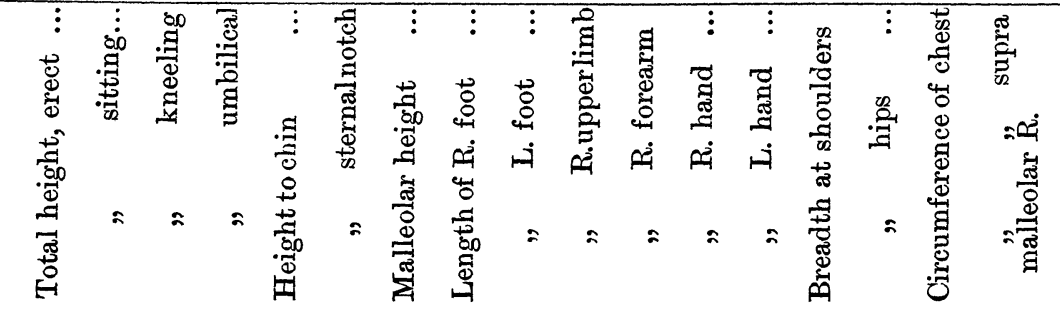 \\
\hline
\end{tabular}

